\title{
Agricultural Use of Sewage Sludge in Paraná State, Brazil: A Decade of National Regulation
}

\author{
Simone Bittencourt \\ Sanitation Company of Paraná-Sanepar, Faculdade Fael, Curitiba, PR 82.800-130, Brazil; \\ sbittencourt@sanepar.com.br or simone.bittencourt@fael.edu.br; Tel.: +55-41-3777-7194
}

Received: 26 September 2018; Accepted: 20 November 2018; Published: 22 November 2018

\begin{abstract}
The agricultural use of sewage sludge brings benefits to soil and plant crops, but due to the possible presence of contaminating substances and pathogenic organisms it is necessary to follow the criteria for safe use for health and the environment. In Brazil, the Conama 375/06 Resolution established criteria and procedures for agricultural use of sewage sludge and Paraná is one of the few states in the country to use this alternative. This case study presents the management process and the results of the agricultural destination of the sludge in Paraná State, Brazil, from 2007, year in which the resolution came into force, to 2017. The management is carried out in two spheres of action: one in the context of the sludge management units (SMU) and another in the agricultural sphere. The sludge is provided free of charge to farmers, which reduces expenses with fertilizers and soil acidity correctives, resulting in economic and social benefits to the communities where it is used. However, from the year 2011 there was a reduction in the amount destined for agricultural use. The requirements of the national regulation make the process complex, overly bureaucratic and burdensome, requiring a review of its criteria.
\end{abstract}

Keywords: biosolid; reuse; wastewater

\section{Introduction}

Sewage sludge presents a significant amount of organic matter and nutrients, being beneficial to the physicochemical and biological characteristics of the soil. However, the residue may contain polluting substances, which must be controlled, when in agricultural use, so as not to negatively affect the environment. Likewise, mitigation measures must be taken for pathogens, to ensure levels that do not present risks to human health.

In Brazil, the Resolution of the National Environment Council Conama 375/06 established criteria and procedures for the agricultural use of sewage sludge seeking to avoid risks to public health and the environment. Among the procedures of the resolution are those related to licensing, sludge-monitoring frequency, the elaboration of agronomic projects, conditions of handling, transport and application. The document also sets out criteria for crops and agricultural areas able to receive the material, locational restrictions, for defining application rate, and for the monitoring of the application areas. Criteria include the determination limits of pathogen, bacteriological indicators and inorganic substances, and the monitoring of 34 organic substances in sewage sludge, not specifying maximum concentration limits [1]. Table 1 presents a summary of the parameters to be determined in sewage sludge for agricultural use. As of 2011, only one class of sludge (Class A) is allowed, until then, there were Class A and Class B. The requirements for sludge Class B are listed in Table 2. 
Table 1. Summary of the parameters to be determined in sewage sludge for agricultural use, according to Conama 375/06.

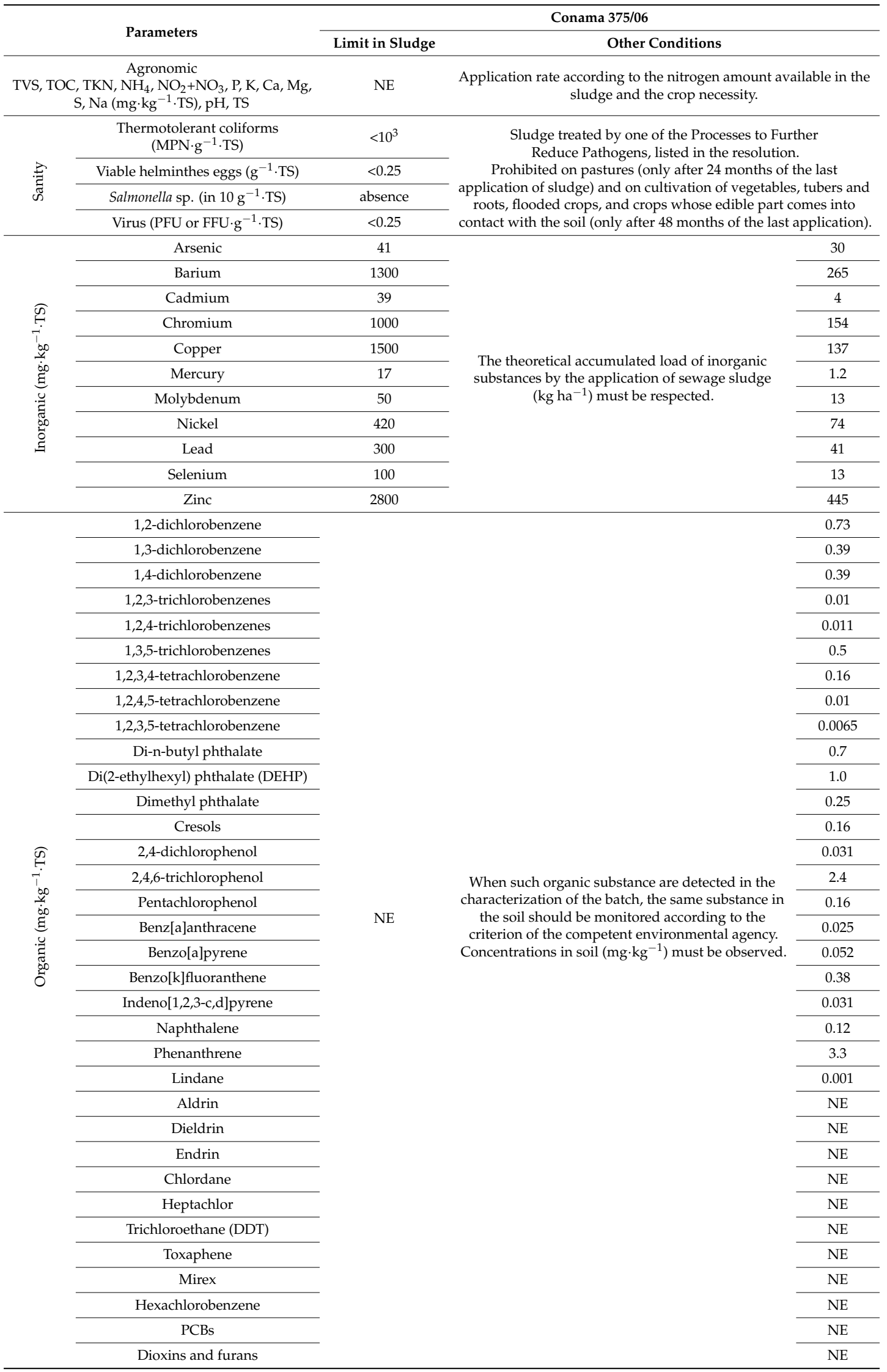


Table 2. Requirements for Class B sewage sludge for agricultural use (allowed until the year 2011), according to Conama 375/06.

\begin{tabular}{|c|c|c|}
\hline Parameters & Limit in Sludge & Other Conditions \\
\hline $\begin{array}{l}\text { Thermotolerant coliforms } \\
\text { (MPN } \cdot \mathrm{g}^{-1} \cdot \mathrm{TS} \text { ) }\end{array}$ & $<10^{6}$ & $\begin{array}{l}\text { Sludge treated by one of the Processes to Significantly Reduce } \\
\text { Pathogens, listed in the resolution. } \\
\text { The use is restricted to coffee cultivation, silviculture, crops for the } \\
\text { production of fibers and oils, with the mechanized application in } \\
\text { ruts or pits, followed by incorporation. }\end{array}$ \\
\hline $\begin{array}{l}\text { Viable helminthes eggs } \\
\left(\mathrm{g}^{-1} \cdot \mathrm{TS}\right)\end{array}$ & $<10$ & $\begin{array}{l}\text { In case of manual harvesting, the application should be made at } \\
\text { least } 6 \text { months before harvesting. } \\
\text { Measures must be taken to restrict public access to the area for a } \\
\text { period of } 12 \text { months after the last application and a sign must } \\
\text { indicate the activities carried out on site. }\end{array}$ \\
\hline Agronomic & \multirow{3}{*}{\multicolumn{2}{|c|}{ The same as presented in Table 1}} \\
\hline Inorganic & & \\
\hline Organic & & \\
\hline
\end{tabular}

Although the Conama 375/06 was elaborated more than 10 years ago, Brazil has few cases of agricultural use of sewage sludge. This fact is a consequence of the limited application of this alternative by the sanitation companies due, among other factors, to the difficulty of complying with the resolution. Criteria and standards are more stringent than those of international rules and do not take into account local and regional specificities, make it difficult, and, in some cases, make it unfeasible to adopt the alternative that is already consolidated worldwide.

Paraná (Figure 1) is the only Brazilian state that performs the agricultural destination following Conama $375 / 06$, because this was a practice already carried out before the validity of the resolution, which allowed work to be made adequate and to continue. The implementation of the agricultural use of sewage sludge in Paraná in 2002, represented the final stage of a studies and evaluations process carried out since 1988 [2,3]. Several researchers and institutions from all over the country participated these studies, which resulted in the production of scientific articles and books, contributing to the elaboration of the Technical Instruction of the state environmental agency regulating the agricultural use of sludge in the state.

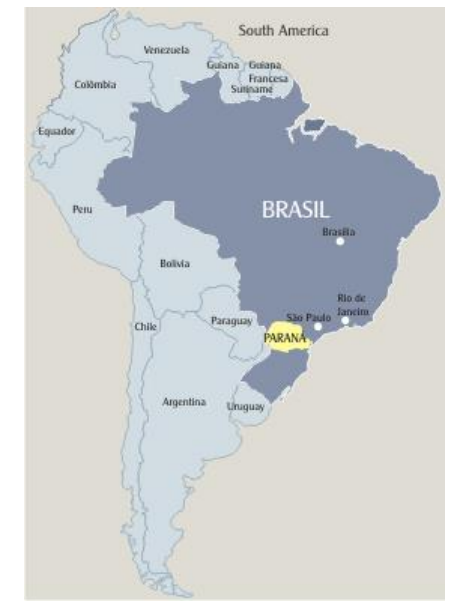

Figure 1. Location of Paraná State in the Brazil map [4].

Another possibility of sewage sludge agricultural use in Brazil is through the normative acts of the Ministry of Agriculture, Livestock and Supply (MAPA), which allow its use as raw material for the production of a MAPA registered product for safe commercialization in agriculture, meeting the established criteria [5-7]. The municipality of Jundiai, São Paulo State, produces and markets organic compound fertilizer registered by MAPA containing sewage sludge [8]. 


\section{Framework of Sewage Sludge Management in Paraná State}

The Sanitation Company of Paraná (Sanepar) operates 243 sewage treatment plants (STP) in 185 municipalities with sanitary sewage systems in Paraná State, which has 399 municipalities [9]. In 2017, 393.7 million $\mathrm{m}^{3}$ of treated sewage generated about 24 thousand $\mathrm{t}$ (dry matter) of sludge in these STP.

The sludge is generated in STP with sewage treatment in systems containing anaerobic reactors of the Upflow Anaerobic Sludge Blanket (UASB) type, with or without post-treatment units, with the exception of Belém STP, where the sludge comes from aerobic biological treatment in an activated sludge system with extended aeration.

In Paraná, the agricultural use of sewage sludge follows the criteria and procedures established in Conama 375/06 and also of the State Environment Cabinet Resolution Sema 021/09 [1,10]. This Resolution defines a sludge management unit (SMU) as a unit, linked or not to a STP, which performs the sludge management generated by one or more STP for agricultural recycling; and the first action is the definition of the SMU, including its location and STPs that comprise it. For this definition, managers take into account:

- $\quad$ availability of area and infrastructure for treatment and storage of the sludge;

- cost of transporting raw sludge from the STP to the place where the SMU is located;

- cost of laboratory analysis, considering that the higher the number of STP that compose a SMU, the lower will be this cost; and

- distance between the agricultural area and the SMU, factor that influences the cost of transportation.

The SMU requests an operating license from the State Environmental Agency and the authorization of the Ministry of Agriculture, Livestock and Supply (MAPA) for commercialization of sewage sludge for agricultural and forestry use, in accordance with Decree 4954 [10,11]. It is possible to visualize, in Figure 2, the operational sequence of the agricultural use of sewage sludge process, which included activities in two spheres of action: one in the context of the SMU and another in the agricultural sphere.

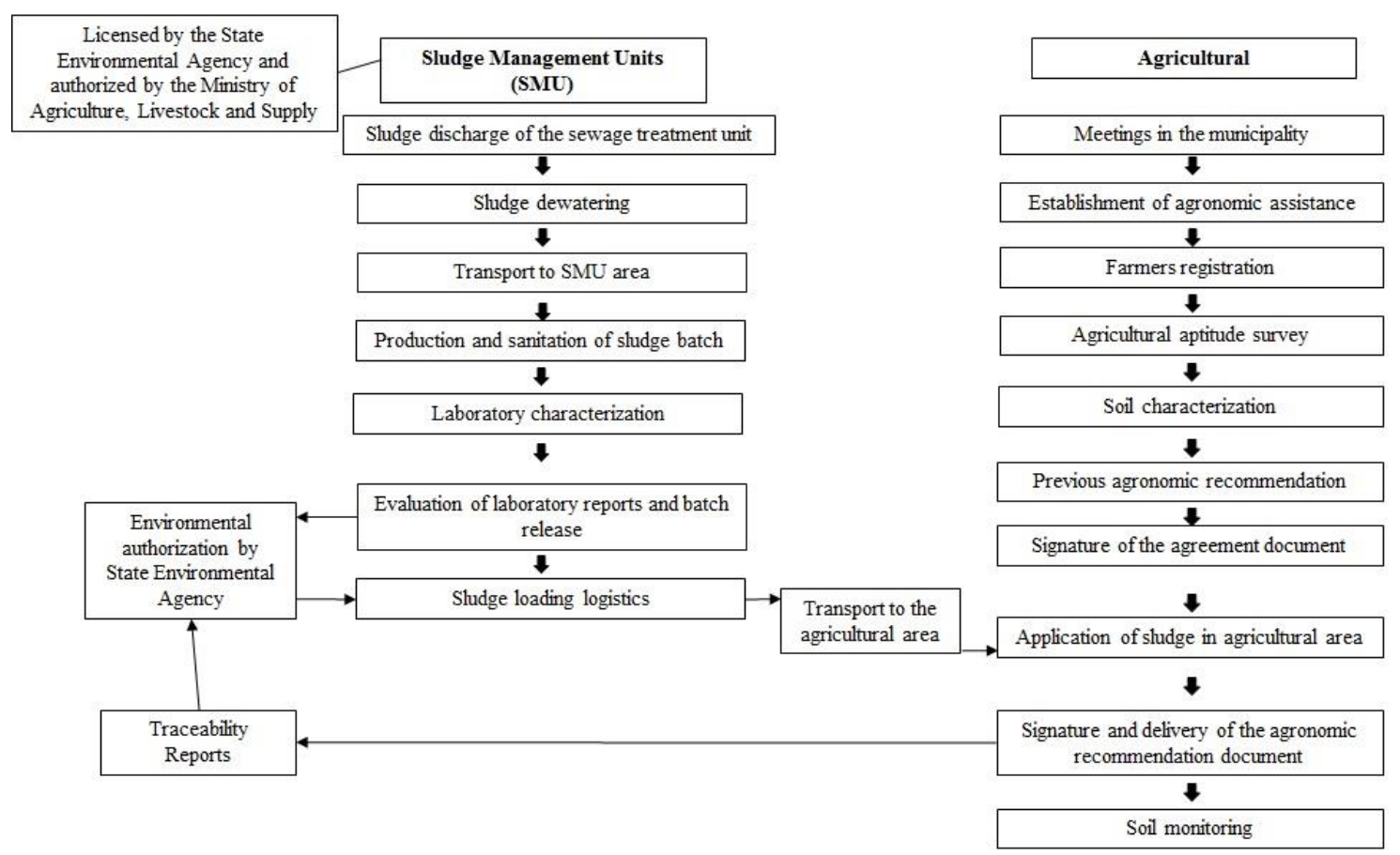

Figure 2. Flowchart of the management process of sewage sludge agricultural use in Paraná. 
In the context of the SMU (Figure 2), after the discharge of the sewage treatment unit, the sludge is dewatered in centrifuges in large STP and in drying beds in smaller STP and after being sanitized by prolonged alkaline stabilization (PAS). By this method, the sludge's $\mathrm{pH}$ is raised to 12 by adding quantities of lime in the proportion of 30 to $50 \%$ total solids (TS) and a subsequent curing phase of at least 30 days. This means that the treated sludge can act as a corrective of soil acidity, representing further savings for the farmers.

After the sanitization, the batches of sewage sludge are characterized according to the legislation (Table 1). For this purpose, samples for laboratory analysis are collected following the criteria established by the instructions of MAPA [12]. The batch is the amount of sewage sludge generated by a SMU in the period between two subsequent samplings, chemical and microbiological [10]. In Paraná, the levels of pathogens found in the sludge comply with all the requirements of the related regulation and the inorganic substance levels remain under the limits of the regulation buy about $90 \%$ [13]. After confirmation that the batch complies the criteria, the SMU requests for the State Environmental Agency the authorization for transport and agricultural use of the sludge batch and it is made available to farmers registered in the programme.

In the agricultural sphere (Figure 2), meetings and technical visits are held with the objective of publicizing the agricultural use of sewage sludge, clarifying the criteria and procedures, and also recording farmers involved. In addition to the farmers, representatives of municipal institutions of agriculture, health and the environment participate in these events.

Farmers are registered only if they produce suitable crops, in areas considered appropriate according Conama 375/06. An agronomist engineer, who takes into consideration the environment aspects that interfere in the erosive soil processes and mechanization, performs the agricultural evaluation of these areas [14].

The sludge application rate is based on the soil and sludge characteristics and crop nutritional needs and, if necessary, supplementary fertilizer is added. Farmers receive technical advice and sign a special agreement certifying they are aware of the requirements and guidance for proper use of the material, and commit to follow them. Sanepar provides sludge free of charge to farmers, which reduces expenses with fertilizers and soil acidity correctives, resulting in economic and social benefits to the communities where it is used.

\section{Agricultural Use of Sewage Sludge in Paraná State}

From 2007 to 2017, 285,836 t of sewage sludge, sanitized by PAS (130,895 t dry matter), were applied in 15,423 ha of agricultural areas of Paraná State; the average application rate was $8.5 \mathrm{t} \cdot \mathrm{ha}^{-1}$ (dry matter). Figure 3 shows the data of agricultural destination of sewage sludge sanitized by PAS from 2007 to 2017 in Paraná, Brazil.

Until 2010, the agricultural use of sewage sludge was carried out primarily in the Curitiba Metropolitan Region (CMR), the state capital. After 2011, there was the diffusion of the process to the municipalities of the interior of the state. From 2012, there was a decrease in agricultural destination (Figure 3) due the impossibility of carrying out the sludge sanitization process in the Belém STP, which had part of its storage and curing area used for the construction of new structural units in the STP. Thus, a greater amount of sludge, from the Belém STP, was destined for landfill and consequently a smaller amount of agricultural area received sludge from this STP. The Belém STP (pertaining to CMR) were responsible for $20 \%$ of the total sludge generated in Paraná State [15]. 


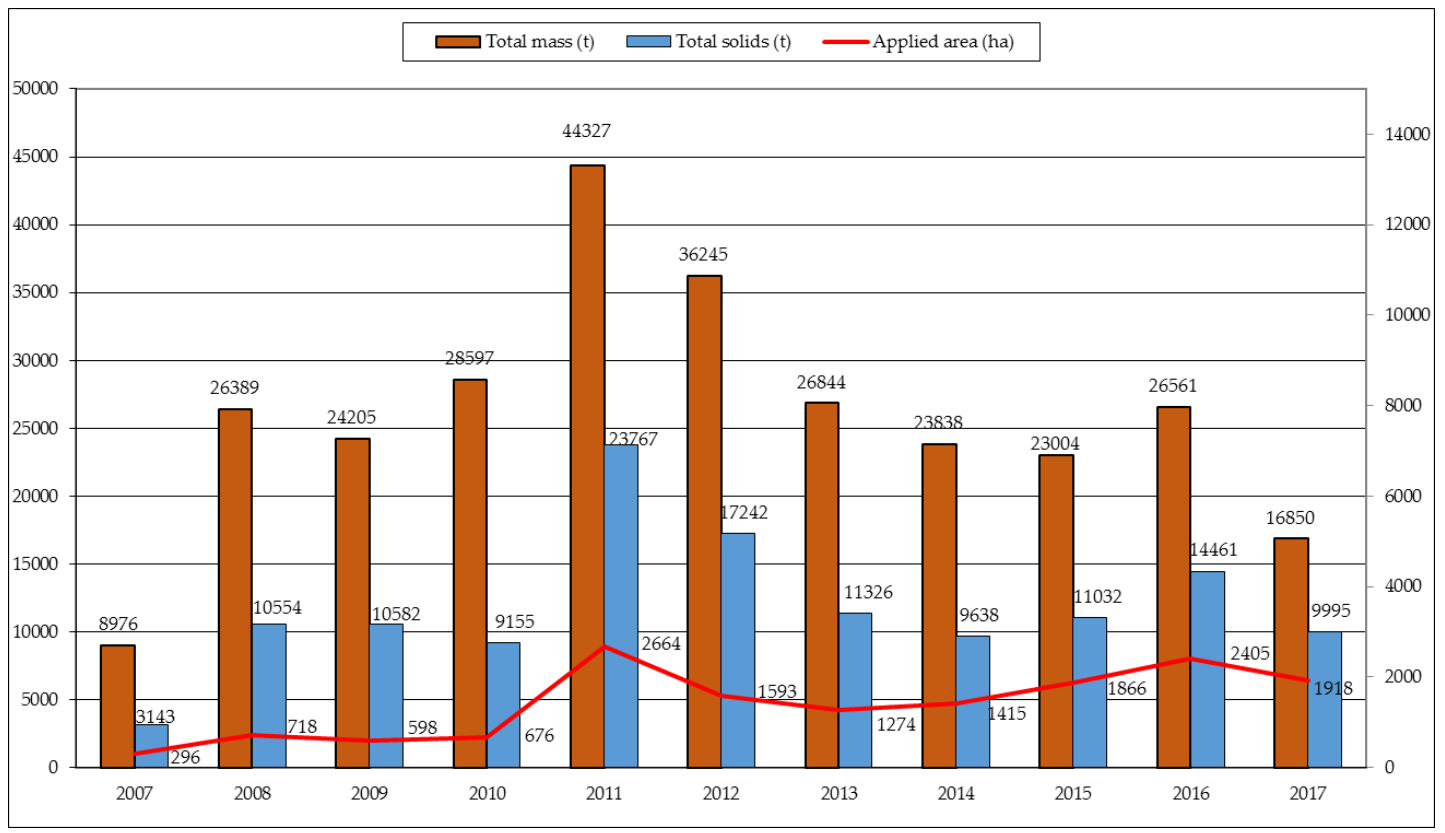

Figure 3. Mass of sewage sludge sanitized by prolonged alkaline stabilization applied to agricultural land, from 2007 to 2017 in Paraná, Brazil.

In the period from 2007 to 2017, 290 farmers applied sludge, in 81 municipalities (Figure 4), for crops of: barley, beans, coffee, corn, eucalyptus and pine, grass implantation, green manure, implantation and postharvest of stone fruit trees, mulberry for silkworms, oat, citrus (orange, pokan, lemon Tahiti), pecans, rubber trees, ryegrass, soybean, sugar cane and wheat.

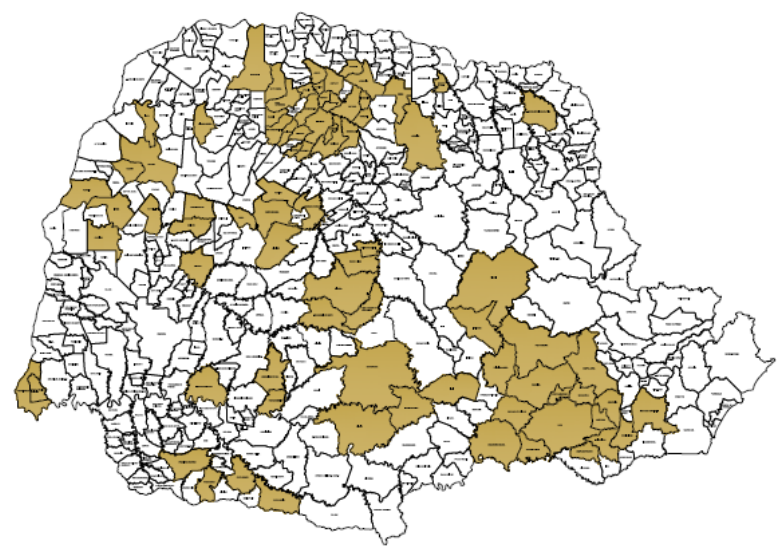

Figure 4. Municipalities with agricultural areas that received sewage sludge, from 20017 to 2017, in Paraná State.

In Paraná, sewage sludge is well accepted by farmers, and despite the decrease in the CMR, its use has been expanding to the interior of the state, where the potential for application to agricultural areas is higher.

\section{Difficulties and Challenges in Agricultural Use of Sewage Sludge in Paraná State}

The expansion of the project has been a major challenge for Sanepar, as sludge recycling was not an operational goal from the start of system design. Thus, improvement of infrastructure and capacity building are necessary.

In addition, it is necessary to face some difficulties related to the complexity of the process management, such as those of transport and distribution logistics, due to the agricultural demand 
concentrated in two seasons of the year (summer and winter crops) and the high number of days with rain in the region, generating difficulties of unloading the material in the agricultural areas. There are also problems in contracting of the laboratory analysis service, due the limited range of laboratories with infrastructure and technical capacity to meet all the criteria established by Conama 375/06.

It is necessary to revise Conama Resolution 375/06, which, in some criteria and procedures, is not applicable to the conditions of Paraná, making it difficult to manage the process of agricultural use of sewage sludge. The rule should make agricultural use of sewage sludge less bureaucratic and costly, without compromising sanitary and environmental safety, so that the criteria and procedures are consistent with Brazilian reality.

Processes to Further Reduce Pathogens to obtain Class A sludge, usually, have higher costs and operational complexity than Processes to Significantly Reduce Pathogens to obtain Class B sludge. Thus, the possibility of using Class B sludge would be the simplest and financially accessible alternative for several sewage treatment systems, being feasible for small municipalities where there are major investment difficulties in the area of sanitation. Standards similar to those internationally could be established for the use of this type of sludge: physical barriers, enforcement controls, monitoring, imposition of collective and individual protection with safety equipment, and definition of allowed crops [16].

In this sense, the Sewage Treatment Thematic Chamber of the Brazilian Association of Sanitary and Environmental Engineering (CTTE Abes) and the National Institute of Science and Technology in Sustainable Sewage Treatment Plants (INCT ETES Sustentáveis) filed in December 2017 a proposal for a review of Conama 375/06 in the National Environment Council. A working group met throughout the year 2017 to develop the proposal, which is currently under review in the council, and aims to present criteria and procedures consistent with technical-scientific development and Brazilian reality, contributing to the diffusion of this alternative, sustainable destination for sewage sludge.

\section{Conclusions}

The management of the agricultural use of sewage sludge in Paraná State, Brazil is carried out in two spheres of action: one in the context of the sludge management units (SMU) and another in the agricultural sphere. From the 2007, year in which the Conama 375/06 Resolution came into force, to $2017,285,836 \mathrm{t}$ of sewage sludge were applied in 15,423 ha of agricultural areas in Paraná State. However, from the year 2011 there was a reduction in the amount destined for agricultural use. It was possible to verify that the requirements of the national regulation make the process complex, overly bureaucratic and burdensome, requiring a review of its criteria.

Funding: This research received no external funding.

Conflicts of Interest: The authors declare no conflict of interest.

\section{References}

1. Diário Oficial [da] República Federativa do Brasil. Available online: http://www2.mma.gov.br/port/ conama/res/res06/res37506.pdf (accessed on 18 August 2017).

2. Lara, A.I. Antecedentes. In Reciclagem de Biossólidos, Transformando Problemas em Soluções; Andreoli, C.V., Lara, A.I., Fernandes, F., Eds.; Sanepar: Curitiba, Brazil, 2001; pp. 14-19.

3. Andreoli, C.V.; Von Sperling, M.; Fernandes, F. (Eds.) Lodo de Esgotos: Tratamento e Disposição Final. Belo Horizonte: UFMG-Departamento de Engenharia Sanitária e Ambiental; Sanepar: Curitiba, Brazil, 2001; p. 484.

4. Paraná in Figures. Available online: http://www.ipardes.gov.br/index.php?pg_conteudo=1\&cod_ conteudo $=3$ (accessed on 22 October 2018).

5. Instrução Normativa No 5, De 10 De Março De 2016. Estabelece As Regras Sobre Definições, Classificação, Especificações E Garantias, Tolerâncias, Registro, Embalagem, Rotulagem E Propaganda Dos Remineralizadores E Substratos Para Plantas, Destinados À Agricultura. Ministério Da Agricultura, Pecuária E Abastecimento; Poder Executivo: Brasília, Brazil, 2016. 
6. Ministério Da Agricultura, Pecuária E Abastecimento. Instrução Normativa SDA No 25, De 23 De Julho De 2009. Estabelece As Normas Sobre As Especificações E As Garantias, As Tolerâncias, O Registro, A Embalagem E A Rotulagem Dos Fertilizantes Orgânicos Simples, Mistos, Compostos, Organominerais E Biofertilizantes Destinados $\grave{A}$ Agricultura. Ministério Da Agricultura, Pecuária E Abastecimento; Poder Executivo: Brasília, Brazil, 2009.

7. Brasil Instrução Normativa SDA No 35, De 4 De Julho De 2006. Aprova As Normas Sobre Especificações E Garantias, Tolerâncias, Registro, Embalagem E Rotulagem Dos Corretivos De Acidez, De Alcalinidade E De Sodicidade E Dos Condicionadores De Solo, Destinados À Agricultura; Poder Executivo: Brasília, Brazil, 2006.

8. Relatório de Ação: Lodo de Esgoto-Fertilizante. Available online: http://arquivos.ambiente.sp.gov.br/ municipioverdeazul/2016/07/ pro-relatorio-acao-jundiai.pdf (accessed on 22 October 2018).

9. Relatório de Administração e de Sustentabilidade. 2017. Available online: http://site.sanepar.com.br/ sites/site.sanepar.com.br/files/relatorio_da_administracao_e_de_sustentabilidade_2017.pdf (accessed on 30 August 2018).

10. Paraná-Secretaria de Estado de Meio Ambiente e Recursos Hídricos. Resolução Sema N. 021, De 30 De Junho De 2009. Dispõe Sobre Licenciamento Ambiental, Estabelece Condições E Padrões Ambientais E Dá Outras Providências, Para Empreendimentos De Saneamento; Diário Oficial: Estado do Paraná, Brazil, 2009; pp. 22-34.

11. Presidência da República. Casa Civil. Subchefia para Assuntos Jurídicos. Available online: http:/ / www. planalto.gov.br/ccivil_03/_ato2004-2006/2004/decreto/d4954.htm (accessed on 30 August 2018).

12. Ministério de Agricultura, Pecuária e Abastecimento. Instrução Normativa no. 53, de 23 de outubro de 2013 (alterada pela IN MAPA no. 06 de 10 de março 2016). Available online: http:/ / www.agricultura.gov.br/assuntos/insumos-agropecuarios/insumos-agricolas/fertilizantes / legislacao/in-53-2013-com-as-alteracoes-da-in-6-de-10-3-16.pdf (accessed on 30 August 2018).

13. Agronomics and inorganics parameters of sludge, sanitized by alkaline stabilization, generated in systems containing anaerobic treatment processes of sewage: A case study of the State of Paraná, Brazil. Scientia Agraria. Available online: https://revistas.ufpr.br/agraria/article/view/48121 (accessed on 25 September 2018).

14. Souza, M.L.P.; Ribeiro, A.N.; Andreoli, C.V.; Souza, L.C.P.; Bittencourt, S. Aptidão das terras do Estado do Paraná para disposição final de lodo de esgoto. Revista DAE 2008, 177, 20-29. [CrossRef]

15. Bittencourt, S.; Ziliotto, M.C.S. Characterization of sewage sludge sanitized: A case study of the Paraná State, Brazil, from 2014 to 2015. In Proceedings of the 14th IWA Leading Edge Conference on Water and Wastewater Technologies, Florianópolis, Brazil, 29 May-2 June 2017.

16. Silva, A.L.; Monção, S.H.; Vianna, R.; Nery, I.M. Alternativas de processo e disposição de lodo de esgoto na agricultura, considerando a atratividade econômica e benefício ambientais. In Congresso Nacional de Saneamento e Meio Ambiente; ABES: São Paulo, Brazil, 2017; p. 5. 